Article

\title{
Evaluation of Transshipment Container Terminals' Service Quality in Vietnam: From the Shipping Companies' Perspective
}

\author{
Thi Yen Pham ${ }^{1}$ and Gi-Tae Yeo ${ }^{2, *}$ \\ 1 Division of Logistics, Faculty of Economics, Vietnam Maritime University, Hai Phong City 180000, Vietnam; \\ phamyen@vimaru.edu.vn \\ 2 Graduate School of Logistics, Incheon National University, 119, Academy-Ro, Yeonsu-Gu, \\ Incheon 22012, Korea \\ * Correspondence: ktyeo@inu.ac.kr
}

Received: 26 February 2019; Accepted: 8 March 2019; Published: 12 March 2019

check for updates

\begin{abstract}
Vietnam is a popular production base for multi-national companies and has become a hub for the global supply chain. Accordingly, to facilitate the increased demands on transportation and to satisfy customers' complicated requirements, more attention has been paid to the service quality of container terminals. Thus, the aim of this paper is to investigate the service quality of transshipment container terminals in Vietnam from the perspective of shipping companies. The Consistent Fuzzy Preference Relation (CFPR) method has been introduced to solve multi-criteria service quality problems using both empirical data and expert knowledge. The results of this study illustrate that terminal accessibility and the proximity to a main trunk route are most important among the principal factors and sub-factors. Additionally, the TCIT terminal's service quality ranks first among the top five container terminals in Vietnam. This study provides stakeholders with insight into competitive factors and risk factors for container terminals and their overall quality of service.
\end{abstract}

Keywords: transshipment; container terminal; service quality; shipping company; Vietnam; Consistent Fuzzy Preference Relation (CFPR)

\section{Introduction}

Along with the development of global trade, liner container shipping is experiencing significant growth [1]. Accordingly, fierce competition in the shipping industry has forced container shipping companies to improve their service quality at minimal cost [2]. In particular, there is a trend toward changing shipping operations from different point-to-point networks to the hub-and-spoke networks, which are characterized by fewer port calls and larger vessels [3]. The hub-and-spoke system can benefit from reduced haul lengths resulting in a lower carbon footprint, reduced cost by economies of scale, and increased service provision. As a result, carriers will not only enhance the cost efficiencies of providing environmentally friendly cargo movements and transport sustainability, but will also strengthen the bargaining positions of terminal operators [4].

Choosing a hub or transshipment container terminal (TCT) has become increasingly important to shipping companies [5], which are affected by many factors. Of those factors, service quality has been emphasized as one of the primary determinants of a terminal's competitiveness [6,7], especially for trunk routes [8,9]. According to the functions of hub shipping, TCTs create a bottleneck in the network; any delay or interruption might escalate the effects, not only on hub-spoke networks, but also on supply chains [10]. Service quality constitutes hardware factors, such as accessibility, equipment, and facilities, and software factors, such as management, information, and terminal 
convenience $[8,11]$. Service quality measurement is required in order to simultaneously consider quantitative and qualitative variables.

Vietnam has become one of the fastest growing nations in the world and has increased its involvement in the global supply chain. Attributed to the favorable business environment, comparative geographical location, political stability, and an integrated global economy, Vietnam has become one of the most rewarded of the ASEAN countries, attracting foreign direct-investment and witnessing the exponential growth of cargo importation and exportation. A master plan for the Vietnamese seaport system was approved in 2014, acknowledging the crucial role the seaport plays in the national economy. In this plan, the deep-sea terminals of the southeast terminals in Ba Ria-Vung Tau and the northern terminals at Lach Huyen in Hai Phong have been designated to handle imported and exported containers for long distance sea routes and function as a combined international transshipment. The ports are able to accommodate larger vessels for transshipment cargoes directly to the European Union and the United States instead of transiting through Hong Kong and Singapore. Despite the aforementioned importance of service quality, there have been insufficient studies about terminal service quality in Vietnam.

This paper aims to evaluate the service quality of the top five container terminals in Vietnam from the perspective of the shipping line companies. The assessment is considered a multiple criteria decision-making (MCDM) problem that deals with both qualitative and quantitative data. In evaluating the logistics facilities of developing countries, qualitative knowledge obtained from experts is significant because of the lack of available secondary data. However, the experts' judgments may be uncertain and imprecise [12], and the fuzzy theory, using linguistic variables, is useful to tackle these problems. This study applies the Consistent Fuzzy Preference Relations (CFPR) method, which is a robust methodology that combines fuzzy theory and MCDM [13], allowing the strengths and weaknesses of targeted container terminals in Vietnam to become recognizable. Additionally, a sensitivity analysis is conducted to test the changes and variations from the evaluation factors that are used. The implications of this study are expected to enhance the understanding of service quality evaluation of transshipment terminals through the case study of Vietnam, a developing country.

The paper is structured as follows: Section 2 reviews the literature on the evaluation of service quality, Section 3 explains the CFPR methodology, followed by Section 4 , which provides the empirical analysis. Finally, Section 5 presents the results and implications, limitations, and possible future work on the issue.

\section{Literature Review}

Due to the nature of the services, characterized by intangibility, heterogeneity, and inseparability [14], measurement of service quality is difficult and complicated [15]. Efforts to develop models and theories to measure service quality have been presented in previous studies, and among them, multi-attribute and multi-dimensional constructs are common approaches to review service quality $[7,16]$. In addition, the SERVQUAL model, which examines five dimensions (tangibles, reliability, responsiveness, assurance, and empathy) and 22 items [17], has been widely used to estimate service quality, though the model has recently been criticized as a universal tool for specific measurement [18-21]. The model entails considerable limitations to the creation of various modifications to applications. The indicated dimensions of SERVQUAL are either too many or too few criteria, requiring the development of several different models to accommodate specific contexts [21], such as the SERVPERE [22] and INTSERVQUAL models [23]; E-S-QUAL [24]; SITEQUAL [25]; and ROPMIS, used in maritime transport [26], which is a modified SERVQUAL model that is used in the banking industry [27], where the laboratory method of decision-making trial and evaluation is combined with an analytical network process to evaluate the service quality of air cargo terminals [28].

Notwithstanding the fact that evaluation of service quality is conducted in various industries, studies of container terminals are exceedingly limited [21]. Kolanovic et al. [11] investigate the dimensions of port service quality using a factor analysis that includes, among a set of 25 attributes, 
port accessibility, port reliability, port functionality, availability of port information, and port flexibility. Ha [8] suggests a framework for evaluating terminal service quality that includes seven factor groups: available information regarding port-related activities, port location, port turnaround time, available facilities, port management, port costs, and convenience for customers. Lu et al. [12] present seven dimensions for a factor analysis to evaluate container terminal service quality, including port facilities and equipment, port cost, customer orientation, IT service, staff service, service efficiency, and general service. Lee and Hu [29] apply an importance performance analysis (IPA) based on Kano's two-dimension quality model to investigate service quality factors, from the perspective of shipping lines, at container ports in Singapore, Shanghai, Hong Kong, Busan, and Kaohsiung. Some studies have applied the SERVQUAL model to measure the service quality of container terminals at Bandar Abbas [7] and Nigerian ports [30]. Yeo et al. [21] apply the ROPMIS model to estimate service quality, considering the social responsibility of Korean container ports, by reviewing resources, outcomes, processes, management, image, and social responsibility. Hemalatha et al. [31] assess the service quality and Indian ranking of container terminal operators using a hybrid of SERVQUAL, an attribute hierarchy model, TOPSIS, and GRP methodologies. Based on the literature review, evaluation of service quality is regarded as a multi-attribute hierarchy structure problem. To solve this problem, MCDM techniques are suggested, such as using an analytical hierarchy process (AHP) and techniques to order preferences, similar to the ideal solution (TOPSIS) methodology used to evaluate the service quality of restaurants [32]; the Fuzzy AHP TOPSIS, used to estimate website service quality [33]; or the Fuzzy TOPSIS used to evaluate intangible resources that affect port service quality [34].

Both quantitative and qualitative attributes contribute to the service quality of container terminals. Using the knowledge and opinions of experts is a significant method of determining qualitative factors and considering the lack of secondary data [35]. However, the preferential model can lead to imprecise and vague expert opinions in the decision-making process due to the limited comparison of numerical values [36]. The fuzzy theory, introduced by Zadeh [37], employs a linguistic scale and has commonly been used to overcome the problems of uncertain and imprecise evaluations [38]. Despite the important role of container terminals in the supply chain, previous studies have primarily investigated the service delivery process or the service outcome, while other determinants, such as value-added services, inter-modal transport services, and coordination between authorities, have not been considered. This study solves the MCDM problems of container terminal service quality evaluation in Vietnam by combining fuzzy theory and MCDM techniques, while the CFPR method, characterized by computational simplicity and consistency [39], is used to assess the performance of the top five container terminals in Vietnam from the shipping companies' perspective.

\section{Methodology}

This study applies the CFPR method developed by Herrera-Viedma et al. [40] to evaluate the service quality of TCTs in Vietnam. The CFPR method establishes pairwise comparison preference matrices using an additive transitivity property. Compared to the AHP or Fuzzy AHP methods, which commonly use pairwise comparison preferences for evaluation, the CFPR method is advantageous in that it shortens the number of questions from $(n \times(n-1)) / 2$ to $(n-1)$ for group $(n)$ criteria, resulting in an increased rate of received responses while eliminating inconsistent situations that have too many questions, thereby saving time and increasing efficiency [41].

This study employs the key definitions and propositions as introduced by Chen and Chao [41]. The scale for comparison uses five levels (Table 1) and the hierarchy criteria for the evaluation involves both quantitative and qualitative factors, resulting in the collection of real data and expert opinions. 
Table 1. Linguistic terms and weight of each criteria's importance.

\begin{tabular}{cc}
\hline Relative Importance & Linguistic Terms \\
\hline 1 & Equally important (EI) \\
2 & Weakly more important (WI) \\
3 & Strongly more important (SI) \\
4 & Very strongly more important (VI) \\
5 & Absolutely more important (AI) \\
\hline
\end{tabular}

\subsection{Preference Relations}

Experts have defined preference relations by scoring a set of criteria and terminals; the value represents the preference rate for the two criteria or terminals. Two preference relations are applied: (1) the multiplicative preference relation, and (2) the fuzzy preference relation.

(1) In multiplicative preference relation $A$, experts illustrate their preference for a set of alternatives $(\mathrm{X})$, denoted by a preference relation matrix $\mathrm{A} \subset \mathrm{X} \times \mathrm{X}, \mathrm{A}=\left(\mathrm{a}_{\mathrm{ij}}\right), \forall \mathrm{i}, \mathrm{j} \in\{1, \ldots, \mathrm{n}\}$, in which $\mathrm{a}_{\mathrm{ij}} \in\left[\frac{1}{5}, 5\right]$ indicates the ratio of the preference relative to the alternative, $x_{i}$ to $x_{j}$.

As $\mathrm{a}_{\mathrm{ij}}=1$ presents an equivalent between $\mathrm{x}_{\mathrm{i}}$ and $\mathrm{x}_{\mathrm{j}}$,

$\mathrm{a}_{\mathrm{ij}}=5$ illustrates that $\mathrm{x}_{\mathrm{i}}$ is absolutely preferred over $\mathrm{x}_{\mathrm{j}}$.

The preference relation $(\mathrm{R})$ is proposed as a multiplicative reciprocal:

$$
\mathrm{a}_{\mathrm{ij}} \times \mathrm{a}_{\mathrm{ji}}=1 \forall \mathrm{i} . \mathrm{j} \in\{1, \ldots, \mathrm{n}\}
$$

(2) In the fuzzy preference relation, the ratio of the preference intensity of terminal $x_{i}$ to that of $\mathrm{x}_{\mathrm{j}}$ is indicated by expert assessments of a set of terminals, in which $(X)$ indicates a positive preference relation matrix $P \subset X \times X$ with membership function $\mu_{p}\left(x_{i}, x_{j}\right)=p_{i j}$. When $p_{i j}=\frac{1}{2}$, no difference exists between $x_{i}$ and $x_{j}\left(x_{i} \sim x_{j}\right)$, whereas $p_{i j}=1$ denotes that $x_{i}$ is absolutely preferred over $x_{j}, p_{i j}=0$ denotes that $x_{j}$ is absolutely preferred over $x_{i}$, and $p_{i j}>\frac{1}{2}$ indicates that $x_{i}$ is preferred over $x_{j}\left(x_{i}>x_{j}\right) .(P)$ is an additive reciprocal:

$$
\mathrm{p}_{\mathrm{ij}}+\mathrm{p}_{\mathrm{ji}}=1 \forall \mathrm{i} . \mathrm{j} \in\{1, \ldots, \mathrm{n}\}
$$

\subsection{Propositions in CFPR}

This method eliminates the problems of inconsistency by constructing decision matrices of pairwise comparisons based on the following three propositions:

Proposition 1. Suppose the existence of a set of alternatives, $X=\left\{x_{1}, x_{2}, \ldots, x_{n}\right\}$, is associated with a multiplicative preference relation, $A=\left(a_{i j}\right)$, with $a_{i j} \in\left[\frac{1}{5}, 5\right]$. The corresponding reciprocal additive preference relation, $P=p_{i j}$, with $p_{i j} \in[0,1]$ to $A=\left(a_{i j}\right)$, is defined as

$$
\mathrm{p}_{\mathrm{ij}}=\mathrm{g}\left(\mathrm{a}_{\mathrm{ij}}\right)=\frac{1}{2}\left(1+\log _{5} \mathrm{a}_{\mathrm{ij}}\right)
$$

where $g$ is a transformation function, and $\log _{5} a_{i j}$ is used because $a_{i j} \in\left[\frac{1}{5}, 5\right]$.

Proposition 2. The reciprocal fuzzy preference relation is $\mathrm{P}=\mathrm{g}(\mathrm{A})$, where $\mathrm{P}=\left(\mathrm{p}_{\mathrm{ij}}\right)$, and the following statements are equivalent:

$$
\mathrm{p}_{\mathrm{ij}}+\mathrm{p}_{\mathrm{jk}}+\mathrm{p}_{\mathrm{ki}}=\frac{3}{2} \forall \mathrm{i}, \mathrm{j}, \mathrm{k}
$$




$$
\mathrm{p}_{\mathrm{ij}}+\mathrm{p}_{\mathrm{jk}}+\mathrm{p}_{\mathrm{ki}}=\frac{3}{2} \forall \mathrm{i}<\mathrm{j}<\mathrm{k}
$$

Proposition 3. The reciprocal additive fuzzy preference relation is $\mathrm{P}=\left(\mathrm{p}_{\mathrm{ij}}\right)$, and the following statements are equivalent:

$$
\begin{gathered}
\mathrm{p}_{\mathrm{ij}}+\mathrm{p}_{\mathrm{jk}}+\mathrm{p}_{\mathrm{ki}}=\frac{3}{2} \forall \mathrm{i}<\mathrm{j}<\mathrm{k} \\
\mathrm{p}_{\mathrm{i}(\mathrm{i}+1)}+\mathrm{p}_{(\mathrm{i}+1)(\mathrm{i}+2)}+\cdots+\mathrm{p}_{\mathrm{j}(\mathrm{i}-1)}+\mathrm{p}_{\mathrm{ji}}=\frac{\mathrm{j}-\mathrm{i}+1}{2} \forall \mathrm{i}<\mathrm{j}
\end{gathered}
$$

If the preference matrix contains values that are not included in the interval $[0,1]$, but are included in $[-a, 1+a]$, in order to preserve the reciprocity and additive transitivity, a linear transformation is required: $\mathrm{f}:[-\mathrm{a}, 1+\mathrm{a}] \rightarrow[0,1]$. The transformation function is then defined as

$$
\mathrm{f}\left(\mathrm{p}_{\mathrm{ij}}^{\mathrm{k}}\right)=\left(\mathrm{p}_{\mathrm{ij}}^{\mathrm{k}}+\mathrm{a}\right) /(1+2 \mathrm{a})
$$

where $a$ is the absolute value of the minimum negative value in the preference matrix.

\subsection{Process of Methodology}

To achieve the objectives of the study, a two-step process of methodology was introduced, as shown in Figure 1.

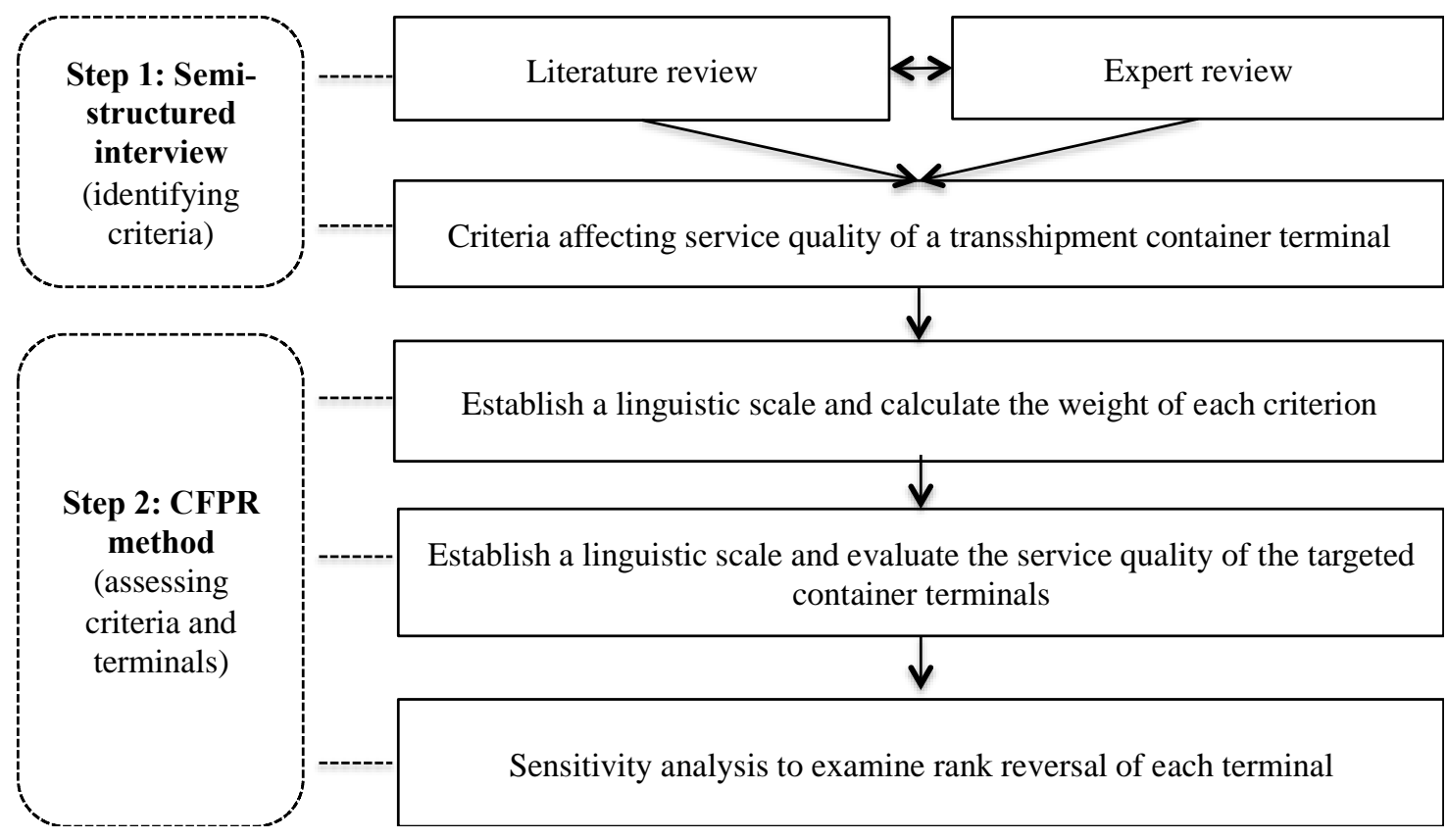

Figure 1. Schematic diagram of the methodology.

Initially, the process was to identify the criteria, including factors and sub-factors, to evaluate the service quality of transshipment container terminals in Vietnam, based on the factors considered in the literature review and examined by experts from shipping line companies calling Vietnamese container terminals. The next step was completed by applying the CFPR method to weigh the factors and targeted terminals using a linguistic scale. Finally, the sensitivity analysis was conducted to examine the rank reversal of the terminals by adjusting the weight of each factor. 


\section{Case Study}

\subsection{Survey Design}

For the first step of methodology, studies related to terminal service quality were circulated among experts to gain insight into the objective. Three experts, each of whom were general or operational managers with more than 15 years of shipping line experience, were interviewed to identify the factors. Within 25 days, between October 3, 2018, and October 27, 2018, four principal factors and 16 sub-factors were identified. The experts were invited to participate in a brainstorming session with open-ended questions to examine whether any factors had not been mentioned, whether any factors overlapped, and whether any factors were unnecessary. Following this session, the experts reached a consensus on a hierarchy of four principal factors and 16 sub-factors, as shown in Table 3.

The second step of the procedure was to analyze the weight of each factor and targeted terminal. To evaluate the service quality of a representative sample of container terminals in Vietnam, the top five terminals of 2017 were identified based on statistics provided by the Vietnam Seaports Association. Among the 68 terminals included in the statistics, CMIT, Tan Cang-Cat Lai (TCCL), Tan Vu, TCIT, and Nam Hai Dinh Vu (NHDV) were listed as the top five and accounted for approximately $70 \%$ of the total container throughput in Vietnam, as shown in Figure 2 and Table 2.

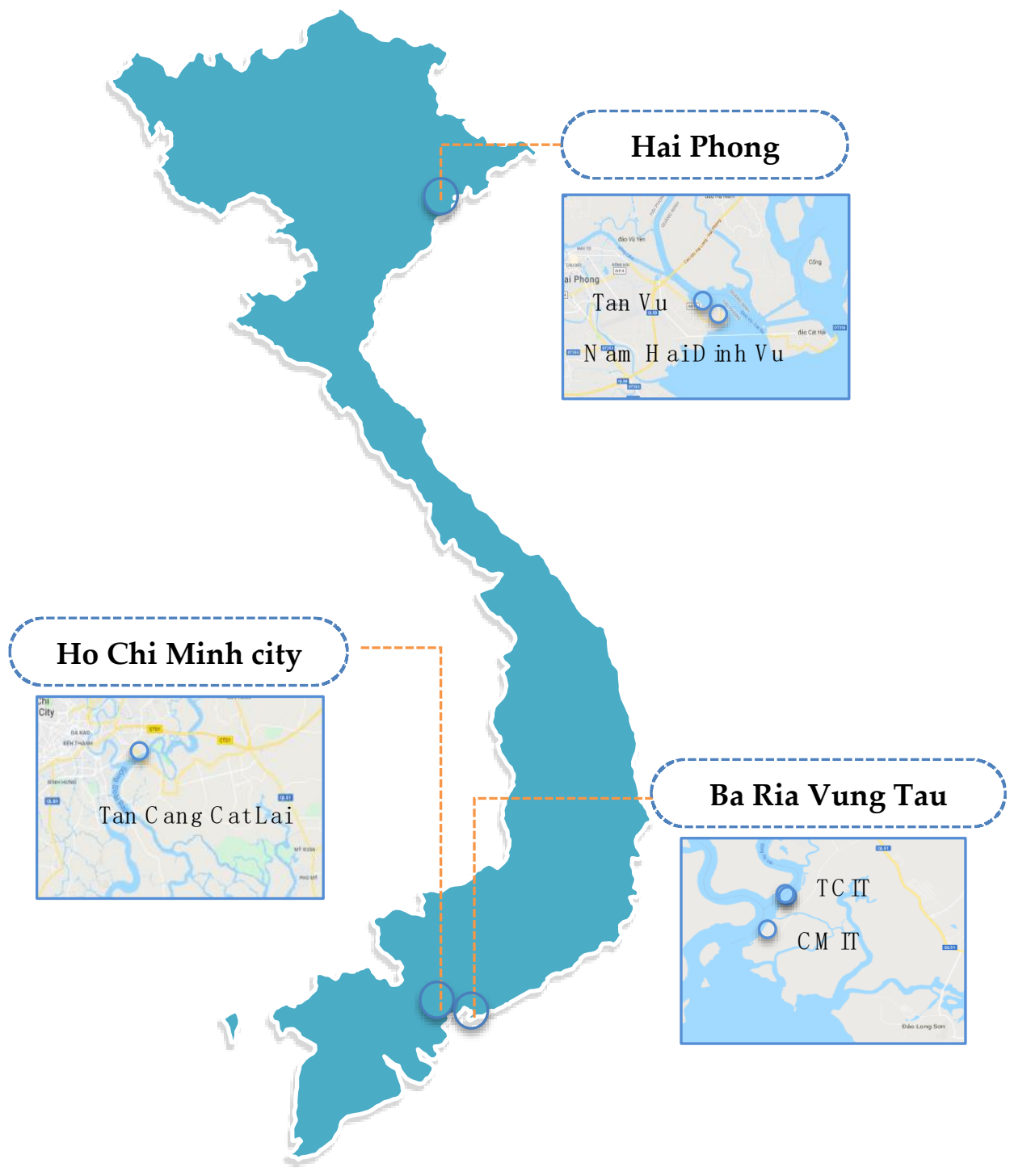

Figure 2. Targeted Vietnamese container terminal locations. 
Table 2. The top five container terminals in Vietnam in 2017.

\begin{tabular}{ccclc}
\hline Terminal & Location & Percentage in Total Throughput & Operators & Year of Operation \\
\hline TCCL & Ho Chi Minh city & 37.30 & Saigon Newport Corporation & 2007 \\
\hline TCIT & Ba Ria Vung Tau & 11.07 & Saigon Newport Corporation, Wanhai, Mitsui OSK and Hanjin & 2011 \\
\hline Tan Vu (Hai Phong) & Hai Phong & 9.28 & Vinalines & 2009 \\
\hline CMIT & Ba Ria Vung Tau & 6.06 & Vinalines, Sai Gon port, APM terminals & 2011 \\
\hline NHDV & Hai Phong & 5.34 & Gemadept Corporation & 2013 \\
\hline Total & & 69.05 & & \\
\hline
\end{tabular}

For the second step, an evaluation was conducted by applying the CFPR method. Seventeen experts, including three who participated in the first step, were invited to complete a survey. To deal with MCDM problems, it is common to consult a panel of 15-20 experts to gain adequate insight. A sample size of 15 experts was considered reasonable for the expert survey [42,43]. According to Kolios et al. [44], the survey should be completed by 20 experts with at least seven years' experience to fulfil the requirements for qualitative validation. This study consulted 17 respondents, each having more than seven years of professional experience with shipping line companies that have called on Vietnamese container terminals. The second survey was conducted between October 29, 2018, and December 9, 2018. The experts were required to present their evaluations using linguistic variables for the factors and sub-factors.

The weights and ranks of each factor were calculated, as shown in Table 3, and the results show that, among the principal factors, terminal accessibility $\left(C_{2}\right)$ was ranked highest. According to the shipping line companies, terminal accessibility is the most important factor when evaluating the service quality of a transshipment terminal. The "terminal function $\left(C_{1}\right)$ " factor is also crucial for deciding the allowances of calling and a vessel's turnaround time at the terminal, including crane productivity per hour, required Under Keel Clearance (UKC) at berth, maximum Length Of All (LOA) restriction at berth, and the number of berths. Terminal management is also considered an important determinant when evaluating service quality in order to provide smooth services for shipping line companies, including procedures and coordination among government agencies, application of IT and EDI, qualifications and skills of port workers and staff, and the effectiveness of marketing and sales departments.

Table 3. Importance and weight of the service quality factors for a transshipment container terminal.

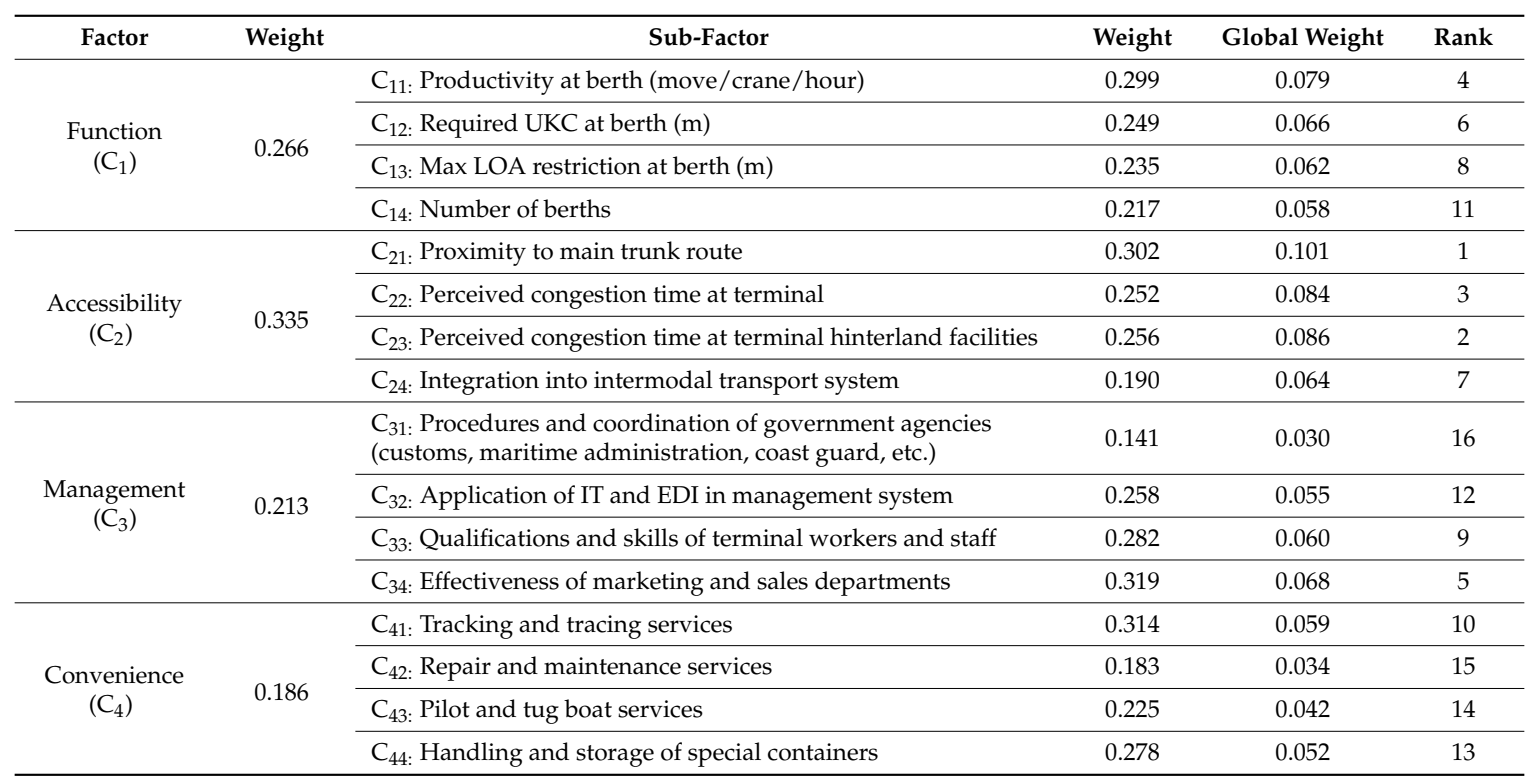


Among the sub-factors, $\mathrm{C}_{21}$ (proximity to main trunk route) is the most important factor in sustaining the convenience of transshipment callings. Additionally, congestion time at port, congestion time at hinterland facilities, and productivities are considered important criteria that greatly effect a vessel's turnaround time at a terminal, driving the ship's operation performance [45]. Integration into intermodal transport is also an important sub-factor and was emphasized by the shipping line companies as a method to optimize different modes of transportation and establish an effective connecting network with hinterlands, potentially diminishing issues related to congestion. Factors related to the required UKC and max LOA restrictions at berth are prioritized to accommodate larger container ships [46]. The effectiveness of marketing and sales departments might strengthen the relationship between terminals and customers and thus affect customers' assessments of a container terminal's service quality.

\subsection{Evaluation of Targeted Terminals' Service Quality}

The service quality of the top five container terminals in Vietnam were evaluated based on 16 sub-factors, including seven quantitative factors and nine qualitative factors. Real data was collected to measure the quantitative factors, as shown in Table 4, while the qualitative factors were assessed by linguistic scale, as expressed by the experts.

Table 4. Data for the objective factors.

\begin{tabular}{lccccc}
\hline \multicolumn{1}{c}{ Factors } & $\begin{array}{c}\text { NHDV } \\
\left(\mathbf{A}_{\mathbf{1}}\right)\end{array}$ & $\begin{array}{c}\text { Tan Vu } \\
\left(\mathbf{A}_{\mathbf{2}}\right)\end{array}$ & $\begin{array}{c}\text { TCCL } \\
\left(\mathbf{A}_{\mathbf{3}}\right)\end{array}$ & $\begin{array}{c}\text { TCIT } \\
\left(\mathbf{A}_{\mathbf{4}}\right)\end{array}$ & $\begin{array}{c}\text { CMIT } \\
\left(\mathbf{A}_{5}\right)\end{array}$ \\
\hline Productivity at berth (move/crane/hour) & 30 & 40 & 40 & 31 & 40 \\
\hline Required UKC at berth $(\mathrm{m})$ & -9.0 & -9.07 & -8.5 & -14 & -14 \\
\hline Max LOA restriction at berth $(\mathrm{m})$ & 455 & 980.6 & 970 & 890 & 600 \\
\hline Number of berths & 2 & 5 & 5 & 3 & 2 \\
\hline Proximity to main trunk routes (nautical miles) & 22.7 & 23.2 & 43 & 18 & 15 \\
\hline Integration into intermodal transport system & \multicolumn{2}{c}{ Two modes (road and inland waterway) } \\
\hline Handling and storage of special containers (number of reefer plugs) & 600 & 800 & 1400 & 1080 & 840 \\
\hline
\end{tabular}

To ensure compatibility between subjective and objective factors, the real data, with different units, was transformed into dimensionless units. The terminal with the most benefits (or the lowest cost) received the highest score.

Table 5 illustrates the evaluation of the top five container terminals in Vietnam, indicating that TCIT maintains the highest service quality among transshipment container terminals, followed by CMIT, TCCL, Tan Vu, and NHDV. TCIT and CMIT were the first deep-water terminals in Cai Mep, along the Thi Vai River, and have an absolute advantage for large container vessels up to 18,000 TEUs, conveniently allowing for direct shipment to the US or the EU without transshipping via Singapore and Hong Kong. The service quality of these two terminals was ranked higher than the quality of other terminals due to the minor congestion issues at each terminal and the available hinterland facilities. Moreover, TCIT and CMIT are both modern terminals that are operated by corporations with global partnerships, providing an international standard of operation. These terminals provide competitive services for customers through an advanced technology system. In particular, TCIT has a comparative advantage over CMIT regarding some typical subjective factors, such as the qualifications and skills of staff and workers and the effectiveness of the marketing and sales departments. Along with the local company, Sai Gon New Port Cooperation (SNP), which is the biggest and most experienced terminal operator in Vietnam, TCIT has been served by three foreign partners: Hanjin Transportation, based in Korea; Mitsui O.S.K Lines, based in Japan; and Wan Hai Lines, based in Taiwan. In addition to a comprehensive connectivity of SNP's regional network, the terminal provides preferential policies and privileges for customers who use certain services, such as inbound laden cargos from TCIT to Cat Lai, without applying additional charges. Although TCIT and CMIT have been designed to allow a 
maximum LOA at berth of $890 \mathrm{~m}$ and $600 \mathrm{~m}$ respectively, CMIT is limited in its ability to simultaneously accommodate two vessels over $300 \mathrm{~m}$ LOA for shipping routes to the US or the EU.

Table 5. Score and rank of the targeted terminals with respect to each sub-factor.

\begin{tabular}{|c|c|c|c|c|c|c|}
\hline Factor & Sub-Factor & $\mathbf{A}_{1}$ & $\mathbf{A}_{2}$ & $\mathbf{A}_{3}$ & $\mathbf{A}_{4}$ & $\mathbf{A}_{5}$ \\
\hline \multirow{4}{*}{$\mathrm{C}_{1}$} & $\mathrm{C}_{11}$ & 0.004 & 0.022 & 0.022 & 0.006 & 0.026 \\
\hline & $\mathrm{C}_{12}$ & 0.007 & 0.008 & 0.005 & 0.023 & 0.023 \\
\hline & $\mathrm{C}_{13}$ & 0.003 & 0.018 & 0.018 & 0.016 & 0.007 \\
\hline & $\mathrm{C}_{14}$ & 0.004 & 0.019 & 0.019 & 0.011 & 0.004 \\
\hline \multirow{4}{*}{$\mathrm{C}_{2}$} & $\mathrm{C}_{21}$ & 0.020 & 0.020 & 0.007 & 0.025 & 0.029 \\
\hline & $\mathrm{C}_{22}$ & 0.020 & 0.019 & 0.004 & 0.020 & 0.021 \\
\hline & $\mathrm{C}_{23}$ & 0.021 & 0.019 & 0.004 & 0.021 & 0.021 \\
\hline & $\mathrm{C}_{24}$ & 0.013 & 0.013 & 0.013 & 0.013 & 0.013 \\
\hline \multirow{4}{*}{$\mathrm{C}_{3}$} & $\mathrm{C}_{31}$ & 0.006 & 0.005 & 0.008 & 0.006 & 0.004 \\
\hline & $\mathrm{C}_{32}$ & 0.011 & 0.008 & 0.015 & 0.012 & 0.009 \\
\hline & $\mathrm{C}_{33}$ & 0.011 & 0.009 & 0.019 & 0.013 & 0.008 \\
\hline & $\mathrm{C}_{34}$ & 0.018 & 0.010 & 0.018 & 0.013 & 0.008 \\
\hline \multirow{4}{*}{$\mathrm{C}_{4}$} & $\mathrm{C}_{41}$ & 0.011 & 0.008 & 0.015 & 0.014 & 0.011 \\
\hline & $\mathrm{C}_{42}$ & 0.007 & 0.007 & 0.009 & 0.007 & 0.005 \\
\hline & $\mathrm{C}_{43}$ & 0.007 & 0.008 & 0.011 & 0.009 & 0.007 \\
\hline & $\mathrm{C}_{44}$ & 0.005 & 0.009 & 0.017 & 0.013 & 0.009 \\
\hline \multicolumn{2}{|c|}{ Total score } & 0.169 & 0.201 & 0.203 & 0.223 & 0.204 \\
\hline \multicolumn{2}{|c|}{ Ranking } & 5 & 4 & 3 & 1 & 2 \\
\hline
\end{tabular}

Notwithstanding that TCCL is the busiest container terminal, accounting for $37.3 \%$ of the total throughput in Vietnam, the terminal's service quality was ranked third among the targeted terminals. TCCL is operated by an experienced container terminal and is highly invested in its facilities, which elevated the management and convenience factors of this terminal over the other terminals, as ranked by the shipping line companies. Although the majority of terminals in Vietnam do not have sufficient container storage or other value-added services within the terminal, the comprehensive inland container depot system run by SNP, which is one of the operators of TCCL, works as an extension to support the terminal operations. Accessibility factors, which are the most important criteria for evaluating the service quality of a TCT, are the least competitive factors for TCCL. Located close to the main industrial zones and demand markets, it would be favorable for TCCL to optimize logistics costs for their customers, but the overload and backlog of containers has a substantial influence on the terminal's operation and the city's transportation infrastructure. A large volume of cargo is transported to and from the terminal by roadway, frequently causing heavy traffic congestion at critical junctions.

The two other container terminals in the north, Tan Vu and NHDV, were ranked fourth and fifth, respectively. These two terminals are located close to each other, and there are almost no differences in accessibility factors, including the issue of gate congestion at peak times. Nevertheless, Tan Vu has a comparative advantage in its capacity to provide more diverse services for customers, such as the number of berths, LOA at berth, and handling and storage of special containers. As an experienced terminal operator in the north, the service quality of Tan $\mathrm{Vu}$ is better than the quality of its rival in terms of the qualifications and skills of the staff and workers. In contrast, NHDV's dynamic and flexible marketing and sales departments have made a positive impression on customer satisfaction. However, the service quality of both northern terminals is less competitive compared with their counterparts in the south, considering the procedures and coordination of government agencies, such as customs, maritime administration, and the coast guard. According to the shipping line companies, policies for implementation and instruction and the regulations of the southern authorities is more supportive and effective, especially for resolving entanglements with customs. 


\subsection{Sensitivity Analysis}

A sensitivity analysis was applied to investigate the robustness of the targeted container terminals' rankings. The analysis examined the uncertainty of output as effected by the uncertainty of input [47,48], resulting in reliable results for the MCDM problems [49]. A sensitivity analysis was conducted by increasing and decreasing the weight of each criteria by equally decreasing and increasing the weights of other criteria [50]. An adjustment of $10 \%$ on priority weights was deemed adequate to examine how sensitive the findings were with respect to the changes [35,51].

Table 6 illustrates how the results correspond to each of the four principal factors after increasing or decreasing each weight by $10 \%$. Figure 3 provides insight into the sensitivity of each terminal's rank with respect to score changes, resulting in the comparative advantages and disadvantages of each identified terminal. The ranking for TCIT and NHDV, ranked first and last, respectively, were insensitive to the change in factor weights. However, other TCTs were sensitive to the change in factor weights, and their rankings were adjusted slightly.

Table 6. Cases for ranking reversal when factors' weights were changed.

\begin{tabular}{lccccc}
\hline & \multicolumn{5}{c}{ Ranking } \\
\cline { 2 - 7 } & $\mathbf{A}_{\mathbf{1}}$ & $\mathbf{A}_{\mathbf{2}}$ & $\mathbf{A}_{\mathbf{3}}$ & $\mathbf{A}_{\mathbf{4}}$ & $\mathbf{A}_{\mathbf{5}}$ \\
\hline \multicolumn{1}{c}{ Current } & 5 & 4 & 3 & 1 & 2 \\
\hline Case 1: Terminal accessibility increase 10\% & 5 & 3 & 4 & 1 & 2 \\
Case 2: Terminal management increase 10\% & 5 & 4 & 2 & 1 & 3 \\
Case 3: Terminal convenience increase 10\% & 5 & 4 & 2 & 1 & 3 \\
Case 4: Terminal function decrease 10\% & 5 & 4 & 2 & 1 & 3 \\
Case 5: Terminal accessibility decrease 10\% & 5 & 4 & 2 & 1 & 3 \\
Case 6: Terminal management decrease 10\% & 5 & 3 & 4 & 1 & 2 \\
Case 7: Terminal convenience decrease 10\% & 5 & 3 & 4 & 1 & 2 \\
\hline
\end{tabular}

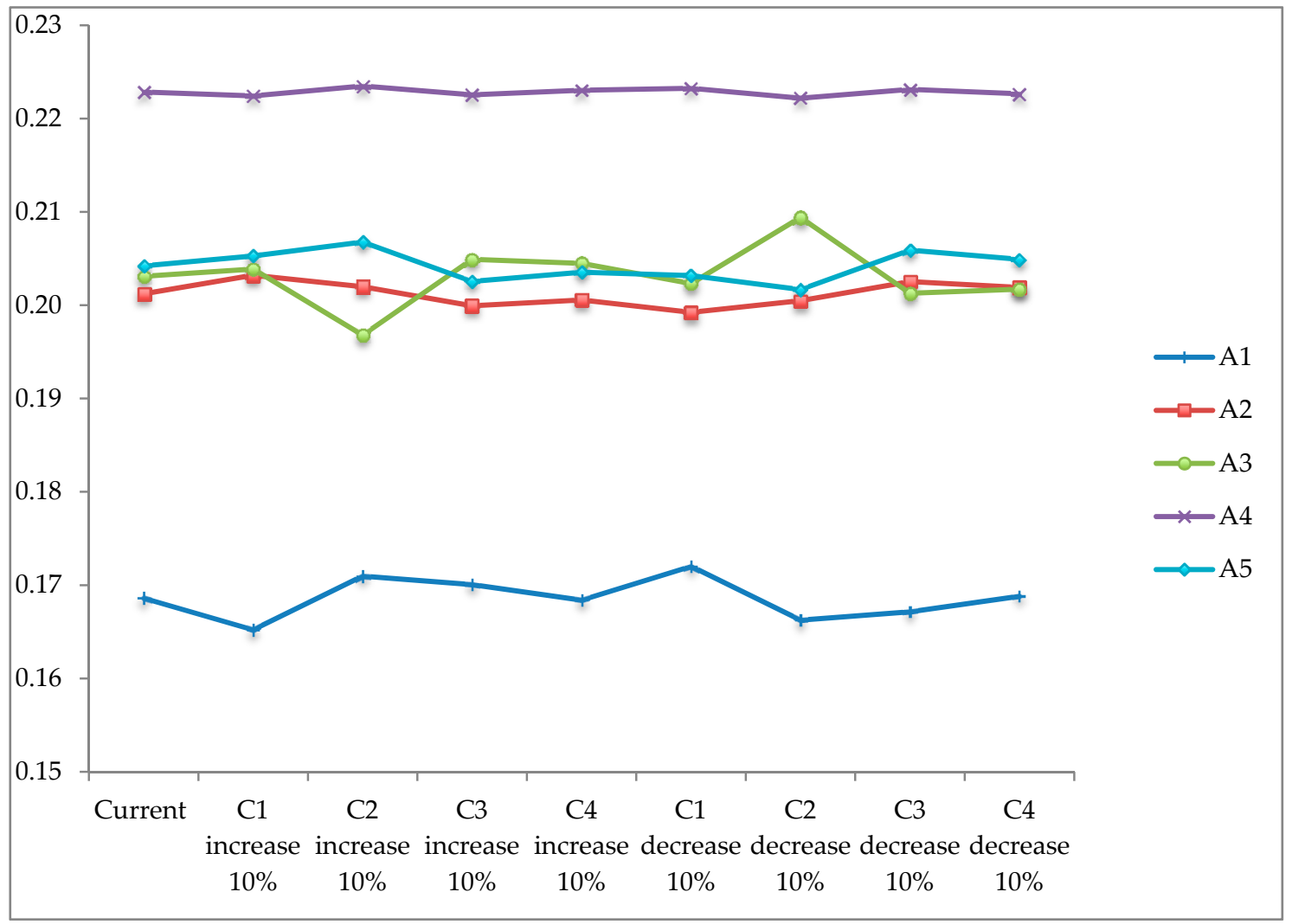

Figure 3. Rank changes with respect to changes in priority weights. 
Ranking reversal occurred among the remaining terminals as the weights changed. The service quality of TCCL would increase significantly if the accessibility factors performed better [43]. Aside from the drawback of its geographical location away from the main trunk route, more attention should be paid to the issue of congestion. Limited connectivity with other modes of transportation is also an issue for TCCL. Reducing the burden on the roadway system by using other modes of transportation, such as inland waterways and railways, would not only contribute to solving the problem of congestion, but would diversify services for customers. Terminal management and convenience, however, are competitive factors for TCCL, which might be emphasized to obtain a higher ranking. Along with TCIT, CMIT is projected to develop deep-sea ports to improve its ability to cater to modern maritime transportation. CMIT's accessibility attributes are emphasized as its competitive advantage in order to increase its service quality ranking [52], as this terminal is closest to the trunk routes. However, the performance of management and the convenience factors should be improved to secure a higher rank. Tan Vu's rank was upgraded as accessibility factors were emphasized and the weight of management and convenience decreased. Tan Vu is the busiest terminal in the north seaport system, but its accessibility attributes are considerably more competitive than its counterpart in the south, which serves over $60 \%$ of Vietnam's container traffic while facing issues of heavy congestion. Although the Tan Vu terminal is managed by an experienced terminal operator and uses modern technologies, compared to other terminals, improvements are needed to increase its service quality.

\section{Conclusions}

The service quality of transshipment container terminals is crucial not only to the supply chain but also to the national economy. Evaluation of service quality by customers, such as shipping companies, is critical to improve the quality of service. An integrated qualitative and quantitative analysis based on CFPR methods was introduced in this study to evaluate the service quality of transshipment container terminals in Vietnam by examining the country's top five container terminals. The results illustrate that terminal accessibility is the most important factor, and proximity to the main trunk route is the most important sub-factor. Among the five terminals examined, TCIT ranked highest for service quality. A sensitivity analysis was conducted to examine rank reversal of the five terminals and to provide insight into each terminal's competitive and risk factors, as these can affect service quality.

This study outlines both academic and industrial implications. Regarding academic contributions, (1) the study solves the problems of service quality measurement by using the MCDM tool and by considering both quantitative and qualitative factors; (2) the CFPR method, using both real data and expert opinions, was employed to investigate the service quality of transshipment terminals; and (3) to overcome the limitations of secondary data in evaluating developing countries, use of expert knowledge is recommended to provide a reliable measurement. Regarding industrial contributions, the findings of this study (1) support container terminal operators in better understanding their customers' requirements and provide an assessment to help operators with strategic developments and improvements; (2) provide shipping companies with insight into the service quality of Vietnamese container terminals, helping shipping companies to make critical decisions about choosing a transshipment container terminal that will allow them to cut costs and provide better service for their customers; (3) support port authorities in developing appropriate policies and strategies to boost the shipping industry and aid in Vietnam's development.

This study provides a stepping stone from which to explore a more suitable hierarchy of the factors and sub-factors used to assess the service quality of transshipment container terminals in Vietnam. There is a limitation to this study. Although there are benefits to evaluating the service quality of shipping terminals through the perspective of shipping line companies, which are the strategic customers of container terminals, examining the perspectives of other stakeholders, such as shippers and logistics service providers, is equally important. To provide more insight into the service quality of shipping terminals, future studies should include other customer groups. 
Author Contributions: G.-T.Y. designed the framework of the paper, reviewed, and edited the paper. T.Y.P. conducted the survey and wrote the first draft of the paper.

Funding: This work was supported by Incheon National University International Cooperative Research Grant in 2018.

Conflicts of Interest: The authors declare no conflict of interest.

\section{References}

1. Zheng, J.; Meng, Q.; Sun, Z. Liner hub-and-spoke shipping network design. Transp. Res. Part E: Logist. Transp. Rev. 2015, 75, 32-48. [CrossRef]

2. Low, J.M.W.; Lam, S.W.; Tang, L.C. Assessment of hub status among Asian ports from a network perspective. Transp. Res. Part A Policy Pract. 2009, 43, 593-606. [CrossRef]

3. Cullinane, K.; Khanna, M. Economies of scale in large container ships. J. Transp. Econ. Policy 1999, 33, 185-208.

4. Lun, Y.H.; Lai, K.H.; Cheng, T.C.E. Shipping and Logistics Management; Springer: Berlin/Heidelberg, Germany, 2010.

5. Chou, C.C. A fuzzy MCDM method for solving marine transshipment container port selection problems. Appl. Math. Comput. 2007, 186, 435-444. [CrossRef]

6. Ng, K.Y.A. Assessing the Attrativeness of Port in the North European Container Transshipment Market: An Agenda for Future Research in Port Competition. Marit. Econ. Logist. 2006, 8, 234-250.

7. Sayareh, J.; Iranshahi, S.; Golfakhrabadi, N. Service Quality Evaluation and Ranking of Container Terminal Operators. Asian J. Shipp. Logist. 2016, 32, 203-212. [CrossRef]

8. Ha, M.S. A comparison of service quality at major container ports: Implications for Korean ports. J. Transp. Geogr. 2003, 11, 131-137. [CrossRef]

9. Chang, Y.T.; Lee, S.J.; Tongzon, J.L. Port selection factors by shipping lines: Different perspectives between trunk liners and feeder service providers. Mar. Policy 2008, 32, 877-885. [CrossRef]

10. Magala, M.; Sammons, A. A New Approach to Port Choice Modelling. Marit. Econ. Logist. 2008, 10, 9-34. [CrossRef]

11. Lu, J.; Gong, X.; Wang, L. An Empirical Study of Container Terminal's Service Attributes. J. Serv. Sci. Manag. 2011, 4, 487-495. [CrossRef]

12. Yeo, G.T.; Wang, Y.; Chou, C.C. Evaluating the competitiveness of the aerotropolises in East Asia. J. Air Transp. Manag. 2013, 32, 24-31. [CrossRef]

13. Pham, T.Y.; Yeo, G.T. A Comparative Analysis Selecting the Transport Routes of Electronics Components from China to Vietnam. Sustainability 2018, 10, 2444. [CrossRef]

14. Parasuraman, A.; Zeithaml, V.A.; Berry, L.L. A conceptual model of service quality and its implication for future research. J. Mark. 1985, 49, 41-50. [CrossRef]

15. Yarimoglu, E.K. A Review on Dimensions of Service Quality Models. J. Mark. Manag. 2014, 2, 79-93.

16. Petrick, J.P. Development of a Multi-Dimensional Scale for Measuring the Perceived Value of a Service. J. Leis. Res. 2002, 34, 119-134. [CrossRef]

17. Parasuraman, A.; Zeithaml, V.A.; Berry, L.L. SERQUAl: A multiple-item scale for measuring consumer perceptions of service quality. J. Retail. 1988, 64, 12-40.

18. Seth, N.; Deshmukh, S.G.; Vrat, P. A conceptual model for quality of service in the supply chains. Int. J. Phys. Distrib. Logist. Manag. 2006, 36, 547-575. [CrossRef]

19. Guo, X.; Duff, A.; Hair, M. Service quality measurement in the Chinese corporate banking market. Int. J. Bank Mark. 2008, 26, 305-327. [CrossRef]

20. Benazic, D.; Dosen, D.O. Service quality concept and measurement in the business consulting market. Trziste 2012, 24, 47-66.

21. Yeo, G.T.; Thai, V.V.; Roh, S.Y. An Analysis of Port Service Quality and Customer Satisfaction: The Case of Korean Container Ports. Asian J. Shipp. Logist. 2015, 31, 437-447. [CrossRef]

22. Brady, M.K.; Cronin, J.J., Jr.; Brand, R.R. Performance-only measurement of service quality: A replication and extension. J. Bus. Res. 2002, 55, 17-31. [CrossRef]

23. Frost, F.A.; Kumar, M. INTSERVQUAL-An internal adaptation of the GAP model in a large service organisation. J. Serv. Mark. 2000, 14, 358-377. [CrossRef] 
24. Parasuraman, A.V.; Zeithaml, V.A.; Malhotra, A. E-S-QUAL: A multiple-item scale for assessing electronic service quality. J. Serv. Res. 2005, 7, 213-233. [CrossRef]

25. Yoo, B.; Donthu, N. Developing a scale to measure the perceived quality of internet shopping sites (SITEQUAL). Q. J. Electron. Commer. 2001, 2, 31-47.

26. Thai, V.V. Service quality in maritime transport: Conceptual model and empirical evidence. Asia Pac. J. Mark. Logist. 2008, 20, 493-518. [CrossRef]

27. Ali, M.; Raza, S.A. Service quality perception and customer satisfaction in Islamic banks of Pakistan: The modified SERVQUAL model. Total Qual. Manag. Bus. Excell. 2017, 28, 559-577. [CrossRef]

28. Hu, Y.-C.; Lee, P.-C.; Chuang, Y.-S.; Chiu, Y.-J. Improving the Sustainable Competitiveness of Service Quality within Air Cargo Terminals. Sustainability 2018, 10, 2319. [CrossRef]

29. Lee, T.; Hu, K. Evaluation of the service quality of container ports by importance-performance analysis. Int. J. Shipp. Transp. Logist. 2012, 4, 197-211. [CrossRef]

30. Ugboma, C.; Ogwude, I.C.; Ugboma, O.; Nnadi, K. Service quality and satisfaction measurements in Nigerian ports: An exploration. Marit. Policy Manag. 2007, 34, 331-346. [CrossRef]

31. Hemalatha, S.; Dumpala, L.B.; Balakrishna, B. Service quality evaluation and ranking of container terminal operators through hybrid multi-criteria decision making methods. Asian J. Shipp. Logist. 2018, 34, 137-144. [CrossRef]

32. Yildiz, S.; Yildiz, E. Service Quality Evaluation of Restaurants Using the Ahp and Topsis Method. J. Soc. Adm. Sci. 2015, 2, 53-61.

33. Lee, C.C.; Chiang, C.; Chen, C.T. An evaluation model of e-service quality by applying hierarchical fuzzy TOPSIS method. Int. J. Electron. Bus. Manag. 2012, 10, 38-49.

34. Pak, J.Y.; Thai, V.V.; Yeo, G.T. Fuzzy MCDM Approach for Evaluating Intangible Resources Affecting Port Service Quality. Asian J. Shipp. Logist. 2015, 31, 459-468. [CrossRef]

35. Wang, Y.; Yeo, G.T. Intermodal route selection for cargo transportation from Korea to Central Asia by adopting Fuzzy Delphi and Fuzzy ELECTRE I methods. Marit. Policy Manag. 2018, 45, 3-18. [CrossRef]

36. Tsai, H.Y.; Chang, C.W.; Lin, H.L. Fuzzy hierarchy sensitive with Delphi method to evaluate hospital organization performance. Expert Syst. Appl. 2010, 37, 5533-5541. [CrossRef]

37. Zadeh, L.A. Fuzzy sets. Inf. Control 1965, 8, 338-353. [CrossRef]

38. Akkaya, G.; Turanoglu, B.; Oztas, S. An integrated fuzzy AHP and fuzzy MOORA approach to the problem of industry engineering sector choosing. Expert Syst. Appl. 2015, 42, 9565-9573. [CrossRef]

39. Chao, P. Exploring the nature of the relationships between service quality and customer loyalty: An attribute level analysis. Serv. Ind. J. 2009, 28, 95-116. [CrossRef]

40. Herrera-Viedma, E.; Herrera, F.; Chiclana, F.; Luque, M. Some issues on consistency of fuzzy preference relations. Eur. J. Oper. Res. 2004, 154, 98-109. [CrossRef]

41. Chen, Y.H.; Chao, R.J. Supplier selection using consistent fuzzy preference relations. Expert Syst. Appl. 2012, 39, 3233-3240. [CrossRef]

42. Wang, Y.; Yeo, G.T. A Study on International Multimodal Transport Networks from Korea to Central Asia: Focus on Secondhand Vehicles. Asian J. Shipp. Logist. 2016, 32, 41-47. [CrossRef]

43. Chen, V.Y.C.; Lien, H.P.; Liu, C.H.; Liou, J.J.H.; Tzeng, G.H.; Yang, L.S. Fuzzy MCDM approach for selecting the best environment-watershed plan. Appl. Soft Comput. 2011, 11, 265-275. [CrossRef]

44. Kolios, A.; Mytilinou, V.; Lozano-Minguez, E.; Salonitis, K. A Comparative Study of Multiple-Criteria Decision-Making Methods under Stochastic Inputs. Energies 2016, 9, 566. [CrossRef]

45. Thai, V.V. Assessing the national port system-The case of Vietnam. In Port Management: Cases in Port Geography, Operations and Policy; Pettit, A., Beresford, A., Eds.; KoganPage: London, UK, 2008; pp. 407-443.

46. Gelareh, S.; Pisinger, D. Fleet deployment, network design and hub location of liner shipping companies. Transp. Res. Part E Logist. Transp. Rev. 2011, 47, 947-964. [CrossRef]

47. Saaty, T.L.; Ergu, D. When is a decision-making method trustworthy? Criteria for evaluating multi-criteria Decision-making methods. Int. J. Inf. Technol. Decis. Mak. 2015, 14, 1171-1187. [CrossRef]

48. Wolters, W.T.M.; Mareschal, B. Novel types of sensitivity analysis for additive MCDM methods. Eur. J. Oper. Res. 1995, 81, 281-290. [CrossRef]

49. Simanaviciene, R.; Ustinovichius, L. Sensitivity Analysis for Multiple Criteria Decision Making Methods: TOPSIS and SAW. Procedia Soc. Behav. Sci. 2010, 2, 7743-7744. [CrossRef] 
50. Haddad, M.; Sanders, D. Selection of discrete multiple criteria decision making methods in the presence of risk and uncertainty. Oper. Res. Perspect. 2018, 5, 357-370. [CrossRef]

51. Leenders, B.P.J.; Velazquez-Martinez, J.C.; Jan, C.; Fransoo, J.C. Emissions allocation in transportation routes. Transp. Res. Part D Transp. Environ. 2017, 57, 39-51. [CrossRef]

52. Banamyong, R. Vietnam in 2030 a Logistics and Infrastructure Perspective. In Vietnam at a Crossroads: Engaging in the Next Generation of Global Value Chains; Hooweg, C., Smith, T., Taglioni, D., Eds.; World Bank Group: Washington, DC, USA, 2017; pp. 69-78.

(C) 2019 by the authors. Licensee MDPI, Basel, Switzerland. This article is an open access article distributed under the terms and conditions of the Creative Commons Attribution (CC BY) license (http://creativecommons.org/licenses/by/4.0/). 